\title{
Prevalence and risk factors of chronic kidney disease in a populated area with highly moving populations
}

\section{Running title: Prevalence and risk factors chronic kidney disease}

\author{
Mohammad Khajedaluee ${ }^{1}$,Sanaz Ahmadi Ghezeldasht ${ }^{2}$, Arman Mosavat $^{2}$, \\ Reza Hekmat ${ }^{3}$,Seyed Abdolrahim Rezaee ${ }^{4, *}$, Tahereh Hassannia ${ }^{5}$,*
}

\footnotetext{
${ }^{1}$ Department of Community Medicine, Faculty of Medicine, Mashhad University of Medical Sciences, Mashhad, Iran

${ }^{2}$ Blood Borne Infections Research Center, Academic Center for Education, Culture and Research (ACECR), Razavi Khorasan, Mashhad, Iran

${ }^{3}$ Department of Internal Medicine, Faculty of Medicine, Mashhad University of Medical Sciences, Mashhad, Iran

${ }^{4}$ Immunology Research Center, Inflammation and Inflammatory Diseases Division, Mashhad University of Medical Sciences, Mashhad, Iran

5 Department of Internal Medicine, Faculty of Medicine, Arash Hospital, Tehran University of Medical Sciences, Tehran, Iran
}

\section{Corresponding authors:}

* T. Hassannia

Endocrinology and Metabolism Research Institute

Tehran University of Medical Sciences, Tehran, Iran

Tel.:+98 5138002376

Fax:+98 5138436626

E-mail:thassannia@yahoo.co.uk https://orcid.org/0000-0001-5815-0667

\section{*S.A.R. Rezaee}

Immunology Research Center, Inflammation and Inflammatory Diseases Division Faculty of Medicine, Mashhad University of Medical Sciences

Azadi-Square, Medical Campus, ZIP code: 9177948564 , Mashhad, Iran.

Tel.: +98 5138002377

Fax: +98 5138436626

E-mail: RezaeeR@mums.ac.ir https://orcid.org/0000-0001-6814-5992

\section{E-mail address and ORCID of the authors:}

M.K: Khajedalueem@mums.ac.ir, https://orcid.org/0000-0001-6275-4455; S.A.G: snz855951@gmail.com, https://orcid.org/0000-0002-0975-6133; A.M: Mosavat@acecr.ac.ir, https://orcid.org/0000-0002-8408-4664;

R.H: HekmatR@mums.ac.ir, https://orcid.org/0000-0002-1108-1307; S.A.R:RezaeeR@mums.ac.ir, https://orcid.org/0000-0001-6814-5992; T.H: thassannia@yahoo.co.uk, https://orcid.org/0000-0001-5815-0667. 
medRxiv preprint doi: https://doi.org/10.1101/2020.10.19.20215004; this version posted October 21, 2020. The copyright holder for this preprint

Background:Chronic kidney disease (CKD) is a major public health problem worldwide. Prevalence and associated risk factors of CKD was evaluated in the greater Mashhad, a highly populated pilgrimage city, in 2018 on 2,976 subjects.

Methods:This study was carried out in the greater Mashhad, a highly populated pilgrimage city, in 2018 on 2,976 subjects. For each participant a standard questionnaire, a physical examination and clinical history were completed. Then biochemical and hematologic tests for kidney function were performed.

Results:Obesity was observed more frequently in subjects with $\mathrm{CKD}$, thus BMI was positively correlated with the prevalence of CKD $(p<0.001)$. Moderately reduced GFR was found in $17.6 \%$ and $7.1 \%$, and severely reduce GFR at $0.7 \%$ and $0.5 \%$, of males and females, respectively $(p<0.001)$.Drug abuse also showed a strong association with CKD $(p=0.004)$, but smoking did not. Using univariate and multivariate logistic regression of decreased estimated GFR $<60$ showed that age $(O R=1.06)$, gender $(O R=2.14)$, diabetes $(O R=1.07)$, hypertension $(\mathrm{OR}=1.39)$ and drug usage $(\mathrm{OR}=3.29)$ were risk factors for $\mathrm{CKD}$; BMI was not. The same statistics showed that only age $(\mathrm{OR}=1.02)$, diabetes $(\mathrm{OR}=2.61)$ and hypertension $(\mathrm{OR}=1.16)$ were risk factors for albuminuria. The prevalence of hypertension $(22.1 \%)$ was a risk factor for $\mathrm{CKD}$, and vice versa. BMI and drug abuse were also risk factors for hypertension, but not smoking.

Conclusion:These findings demonstrated that progression of CKD and hypertension in any population should be considered in the context of changes in human behaviours, etiology, disease severity, co-occurring diseases, addiction and priority of therapy over prevention.

Keywords: Cardiovascular risk, chronic kidney disease (CKD), Iran, prevalence, risk factors 
medRxiv preprint doi: https://doi.org/10.1101/2020.10.19.20215004; this version posted October 21, 2020. The copyright holder for this preprint (which was not certified by peer review) is the author/funder, who has granted medRxiv a license to display the preprint in perpetuity.

All rights reserved. No reuse allowed without permission.

\section{INTRODUCTION}

Chronic kidney disease (CKD) is becoming a major problem worldwide for health authorities because of its trend progression and its association with cardiovascular diseases.It is among the main causes of death that has radically increased in the last 30 years, due to aging, urbanization, and emerging diabetes, and hypertension, lack of access to adequate healthcare,herbal medication and incomplete knowledge of its pathogenesis.Nowadays, researchershave demonstrated that diabetes and hypertension are the two main causes of kidney disease in the developed world. ${ }^{1}$

The most important danger for patients and health authorities are, firstly, the risk of the disease progressing toward end-stage renal disease (ESRD), a statusrequiringhemo or peritoneal dialysis or kidney transplantation,which are costly and debilitating. Secondly, $\mathrm{CKD}$ is ahigh-risk factor for cardiovascular diseases (CVD).$^{2-4} \mathrm{By}$ understanding the risk factors and pathogenesis of CKD in its early stages, it is possible to reduce the occurrence of CVD and ESRD.Because of the nature of the early stages of CKD, it is not primarily diagnosed until its progression toward kidney damage has commenced; therefore, more studies and attention are needed to reduce the development and progression of renal failure and its adverse consequences. Even serious kidney damage can be delayed through early diagnosis and CKD therapy. 5

According to $2002 \mathrm{KDOQI}$ Guidelines, definition of CKD is a glomerular filtration rate (GFR) below $60 \mathrm{~mL} / \mathrm{min} / 1.73 \mathrm{~m} 2$ for three months or more, irrespective of the cause and with or without evidence of kidney damage. ${ }^{7}$ GFR is assessed by serum creatinine usingthe Cockcroft and Gault (CG) and Modification of Diet in Renal Disease (MDRD) equations for adults. $^{7,8}$

In the United States, a national survey, demonstrated that the prevalence of CKD had an increased trend from $10 \%$ in $1988-1994$ to $13.1 \%$ in $1999-2004 .{ }^{9}$ Studies also showed a high 
prevalence of CKD in Japan's general population, around $18.7 \% .^{10,11}$ In Asia, Europe and Australia, similar trends of the high prevalence of CKD have been reported. ${ }^{12}$ particularly in the Middle East.In Iran, a high prevalence of CKDhas been observed among people over age 20. In another study, the prevalence of CKD was calculated by MDRD for the general population of Tehran, and was found to be $18.9 \%$ (95\% CI 18.2, 20.6). ${ }^{13}$ progression, it is pivotal to assessaccurate prevalence rates at particular stages in different geographic regions. Therefore, in this study,the prevalence and the associated risk factors of 
medRxiv preprint doi: https://doi.org/10.1101/2020.10.19.20215004; this version posted October 21, 2020. The copyright holder for this preprint (which was not certified by peer review) is the author/funder, who has granted medRxiv a license to display the preprint in perpetuity.

METHODS

101

102

103

104

105

106

107

\section{Study population and sample size}

All participants completed a written informed consent, which was approved by the Biomedical Ethics Committee of Mashhad University of Medical Sciences. The study was performed on the general population of the greater Mashhad between May and September 2018.

The list of all households under coverage of the city's 20 district health centres (primary health and treatment services) was used for sampling.A random sample of the households was taken, stratified by healthcare centre to achieve a distribution similar to the original population. In each household, one person above the age of 16 was recruited so that the study included the both genders as well as appropriate percentiles for ages according to the 2011 census in each district.There were 2,976 full participants in this study. Of this sample, 1,045 were male $(35.1 \%)$ and $1,931(64.9 \%)$ were female.

Prior to the beginning of the study a four-day official workshop was coordinated by a nephrologist, a socio-medical specialist and a biochemist for one physician from each of the district health centres to discuss the kidney failure signs and symptoms, staging, hypertension and the priority of precise data collection.Then, medical examinationswere performed on participants and histories and demographic and anthropometric data were taken by these physicians. Blood pressure was assessed by a mercury sphygmomanometer. Height and weightweremeasured using aSeca217 and 707, respectively. Body mass index (BMI) was also recorded. The inclusion criteria including;age $>16$ year, resident of the district more than 1 yearand filling informed consent. Furthermore, the exclusion criteria were dialysis treatment, any transplantation, malignancy, HIV infection diagnosis and pregnancy or pregnancy within the past 6 months. The flowchart 1 shows all the relevant of study variables. 
medRxiv preprint doi: https://doi.org/10.1101/2020.10.19.20215004; this version posted October 21, 2020. The copyright holder for this preprint

(which was not certified by peer review) is the author/funder, who has granted medRxiv a license to display the preprint in perpetuity.

All rights reserved. No reuse allowed without permission.

\section{Sample collection and serological assay}

Blood samples were taken between 8-10am after a 10-12 hours overnight fast according to the protocol of Mashhad's ACECR-Central Medical Lab.Analyses of blood biochemical agents such as fasting glucose, total cholesterol (TC) and triglyceride (TG), creatinine and BUN concentrations were carried out at the Central Laboratory of ACECR using aSelectra 2 autoanalyser (Vital Scientific, Netherlands).

Urinary factors, includingcolour, appearance, $\mathrm{pH}$, protein, ketones, $\mathrm{Hb}$, bilirubin,urobilinogen, blood, glucose, nitrite, bacteria, parasites, crystal, mucus, yeast, candida, cast,WBC, RBC and Epithelial cell were examined.

\section{Definition of chronic kidney disease}

A simplified MDRD equation ${ }^{14}$ was used for GFR estimation in this study as follows: GFR $(\mathrm{mL} / \mathrm{min} / 1.73 \mathrm{~m} 2)=186.3 *($ serum creatinine $)-1.154 *($ age $)-0.203 *(0.742$ if female $) *$ (1.21 if African American).

\section{Statistical analysis}

Data were analysed using SPSS version 16(SPSS Inc., Chicago, IL, USA). The analyses were carried out using descriptive statistical indexes including standard deviation, mean and a confidence interval at $95 \%$.

For data analysis, the distributions of the variables were estimated using the KolmogorovSmirnov test.For variables with normal distribution, the parametric test was used, and, for others, non-parametric tests were used. For qualitative variables, a chi-square test was used.For non-normal distributed variables, Man Whitney and Kruskal Wallis tests were used.For quantitative variables, $t$-student and one-way ANOVA tests were used. Univariate and multivariate logistic regression tests were employed to discover risk factors for CKD. The resultswere significant if $p \leq 0.05$. 
medRxiv preprint doi: https://doi.org/10.1101/2020.10.19.20215004; this version posted October 21, 2020. The copyright holder for this preprint (which was not certified by peer review) is the author/funder, who has granted medRxiv a license to display the preprint in perpetuity.

\section{RESULTS}

\section{Socio-demographic data}

Out of the 2,976-full-participant study population, 1,045 of them were male (35.1\%) and $1,931(64.9 \%)$ were female. A total of $22.1 \%$ participants (20\% of women and $52.9 \%$ of men) had hypertension, $8.8 \%$ (6.8\% women and $12.6 \%$ men) had diabetes, and $39 \%$ had a history of chronic diseases. Finally, $4.86 \%$ of women and $14.9 \%$ of men had a history of smoking and $1.8 \%$ of participants were drug users(Table 1$)$.

As Table 1 shows, the mean age of the population was $43.52 \pm 14.69$ years, ranging from 16- 60, with an age distribution profound in the 40-59 level and older, in which CKD seems to be more common.A total of $36 \%$ of the subjects were under the age of 40 , and $60 \%$ were over the age of 40 . This indicates that age is a risk factor for CKD, with CKD being more frequent in older participants $(p<0.001)$. The mean BMI of 25-30 was more frequent in this study $(39.8 \%)$,and is in the range of being overweight. Taken together, $22.2 \%$ of the subjects were in the range of obesity, $39.8 \%$ were in range of being overweight, and $38.1 \%$ fell in the normal range. Around $62 \%$ of the population fell in the range of being overweight,which are risk factors for $\mathrm{CKD}$ and $\mathrm{CVD}$. BMI has a strong association with the prevalence of CKD $(p<0.001)$, and obesity in this population was more frequent where CKD was more prevalent. While smoking was not significant factor for CKD occurrence, drug abuse had a strong association with CKD $(p=0.004)$.

Furthermore, although the mean albumin in urine in men $(21.8 \pm 2.63)$ and women $(18.4 \pm 1.72)$ was not statistically significant, the mean urine creatinine in men $(142.82 \pm 3.04)$ and women $(125.8 \pm 2.14)$ was significant $(p<0.001)$. The mean concentration of serum creatinine in men was $1.23 \mathrm{mg} / \mathrm{dL}$ and in women was $1.04 \mathrm{mg} / \mathrm{dL}$. This difference was significant $(p<0.001)$. The mean estimated GFR, $71.29 \mathrm{~mL} / \mathrm{min} / 1.73 \mathrm{~m}^{2}$ in men was 71.29 and 
medRxiv preprint doi: https://doi.org/10.1101/2020.10.19.20215004; this version posted October 21, 2020. The copyright holder for this preprint (which was not certified by peer review) is the author/funder, who has granted medRxiv a license to display the preprint in perpetuity.

All rights reserved. No reuse allowed without permission.

in women was 84.84 ,a statistically significant difference $(p<0.001)$. Taken together, the indices for renal function in females was generally better than in men (Table 1).

\section{Kidney function and albuminuria}

According to the GFR, $\mathrm{mL} / \mathrm{min} / 1.73 \mathrm{~m}^{2}$, about $12.1 \%$ of men and $40.3 \%$ of women had a GFR over 90 and in range of normal; $69 \%$ of men and 52\% women had a GFR 60-89, in range of mildly reduced kidney function. Moreover, around $17.6 \%$ of men and $7.1 \%$ of women had moderately reduced GFR, and $0.7 \%$ of men and $0.5 \%$ of women had severely reduced GFR. The differences between men and women in these categories were significant $(p<0.001)$. Table 2 demonstrates kidney function according to GFR, $\mathrm{mL} / \mathrm{min} / 1.73$ $\mathrm{m}^{2}(\mathrm{~A})$ and albuminuria (B).

\section{Prevalence of chronic kidney disease}

In men, $10.8 \%, 68.3 \%, 20.2 \%, 0.5 \%, 0.2 \%$ wasin CKD stages of $1-5$, respectively. However, in women, there were radically different distributions of CKD stages: $44.4 \%$, $51.1 \%, 4.2 \%, 01 \%$ and $0.2 \%$ in stages $1-5$, respectively $(p<0.001)$ (Table 3 ).

\section{Main risk factors of CKD manifestation}

Using univariate and multivariate logistic regression of decreased estimated GFR $<60$ $\mathrm{mL} / \mathrm{min} / 1.73 \mathrm{~m} 2$ showed that age $(\mathrm{OR}=1.06)$, gender $(\mathrm{OR}=2.14)$, diabetes $(\mathrm{OR}=1.07)$, hypertension $(\mathrm{OR}=1.39)$ and drug use $(\mathrm{OR}=3.29)$ were the primary risk factors for $\mathrm{CKD}$ in this population, and that BMI was not (Table 4-A). However, univariate and multivariate logistic regression results showed that only age $(\mathrm{OR}=1.02)$, diabetes $(\mathrm{OR}=2.61)$, and hypertension $(\mathrm{OR}=1.16)$ were risk factors for albuminuria (4B).

The distributions of estimated GFR and albuminuria are shown in Fig. 1. It was expected that there would be a normal distribution of GFR and albumin-to-creatinine( $\mathrm{Al} / \mathrm{Cr}$ ) ratio, as GFR had a symmetric normal distribution.However, the Al/Cr ratio was not normal, and most of the subjects (40\%)hadratio indices between 5 and 24.99. The prevalence of subjects with 
medRxiv preprint doi: https://doi.org/10.1101/2020.10.19.20215004; this version posted October 21, 2020. The copyright holder for this preprint

(which was not certified by peer review) is the author/funder, who has granted medRxiv a license to display the preprint in perpetuity.

All rights reserved. No reuse allowed without permission.

199

200

201

202

203

204

205

206

207

208

209

210

GFR below $60 \mathrm{~mL} / \mathrm{min} / 1.73 \mathrm{~m}^{2}$ was around $12.8 \%$, but most of the subjects $(72.6 \%)$ had GFR between $60-100 \mathrm{~mL} / \mathrm{min} / 1.73 \mathrm{~m}^{2}$.

The prevalence of CKD increased with age, as expected. As Fig.2 shows, the under curve area demonstrates the percentage of CKD stages for each age category; for example, the subjects in stage 3 increased from $1.30 \%$ in age groups $<30$ to $3 \%, 10 \%, 23.3 \%$ and $39.8 \%$ in age groups of 30-39, 60-69 and >70, respectively. There were no cases of stages of 4 and 5 in age groups <30, 30-39, 40-59 and 60-69. However,stage 4 and 5 cases were found in $0.30 \%$ and $0.40 \%$ of participants in age groups $40-59$ and in $1 \%$ for the age group $>70$ years. These trends in increasing in CKD stages according to age were expected, as instances of a GFR below $90 \mathrm{~mL} / \mathrm{min} / 1.73 \mathrm{~m}^{2}$ increases with age. 
medRxiv preprint doi: https://doi.org/10.1101/2020.10.19.20215004; this version posted October 21, 2020. The copyright holder for this preprint (which was not certified by peer review) is the author/funder, who has granted medRxiv a license to display the preprint in perpetuity.

All rights reserved. No reuse allowed without permission.

\section{DISCUSSION}

In this study, the prevalence of CKD was investigated in Mashhad, a city with a population of more than 3 million inhabitants and a moving population of around 20 to 30 million people per year. Mashhad is the second-most-populated city in Iran and is the capital of Razavi Khorasan province. It has a highly-mixed population of Arab, Turkic and Mongolian and Afghan tribes. This diversity makes it a city of interest for an investigation into the main risk factors for CKD.

Although smoking was not a risk factor, addiction was a strong risk factor $(\mathrm{OR}=3.25)$ for CKD occurrence. There are two reasons for this.Firstly, opium is the main drug that is popular in Iranian drug culture, and it can cause kidney damage. ${ }^{15}$ Our findings in the lab show that most of commercial opiumis contaminated by heavy metals, particularly lead which can intensify tissue injury. ${ }^{16}$ Secondly, many young drug users use amphetamine derivatives. These drugs and their contaminations are more likely the main reasons for renal malfunction in drug users.

The progressive aging of the subjects and the epidemics of obesity and diabetes in many countries complicates to the worldwide burden of CKD. ${ }^{17}$ A cohort study in Iran between 1997 and 2000 demonstrated with the MDRD equation that the overall prevalence of CKD was $18.9 \%$ and age-adjusted prevalence was $14.9 \% .{ }^{13}$ In our study, the prevalence of CKD in Mashhad was $10 \%$ strongly lower than other studies in Iran.A precise scientific evaluation of some of those studies clarifies that their methodology were not adjusted for CKD and at the planning stage not intended to measure its prevalence, thus may have had biases.

This study demonstrated that the age distribution is profound in the age group 40-59 and older, in which CKD seems to be more common; $36 \%$ of the subjects were between 40 and 60. This was expected as CKD is more frequent in older subjects $(p<0.001)$.CKD affects $10 \%$ to $15 \%$ of adults in the United States, Europe, and Asia ${ }^{9,18}$, and prevalence increases with 
medRxiv preprint doi: https://doi.org/10.1101/2020.10.19.20215004; this version posted October 21, 2020. The copyright holder for this preprint (which was not certified by peer review) is the author/funder, who has granted medRxiv a license to display the preprint in perpetuity.

All rights reserved. No reuse allowed without permission.

age. ${ }^{9}$ This implies that low eGFR reflects only aging, and some studies suggest that existing CKD guidelines should be used in older population or subjects. ${ }^{19-22}$

In the present study, hypertension in uni- and multi-variant regression was not a risk factor in our region as a middle class population. CKD is a multi-factor disease with wide variation in risks the world. Growing evidence demonstrated that even diabetes and hypertension in more developed countries associated with $\mathrm{CKD}$, in low and middle income countries apart from race and age, other risk factors such as herbal medications, life style, diet, noncommunicable diseases, genetic factors, and water scarcity factors had strong association with kidney failure. ${ }^{23,24}$

On the other hand, in the literature there are studies in favour or opposition of association between hypertension and renal failure, in Italy compared with the USA, diabetes and hypertension largely fail to explain the lower prevalence of CKD. Furthermore, in a review, by Luca De Nicola, these controversial results have been discussed, it is stated that "four countries with lower CKD prevalence $(6.8 \%$ overall) had a higher (rather than lower) prevalence of hypertension and then the four countries showing higher CKD prevalence $\left(12.2 \%\right.$ overall)" ${ }^{23}$

Therefore, in our region with emphasis on the heterogeneity of the residents, hypertension did not meet significant association with CKD. Taken together, by deep observation on renal failure and staging, our understanding of hypertension and CKD as direct cause radically changed, it is more likely that two factors being possibly attributable to the amelioration of kidney damages including, endothelial dysfunction and inflammation.

The mean BMI of 25-30 (overweight) was more frequent in this study (39.8\%), which, using conventional statistical analysis, shows that obesity is a risk factor for $\operatorname{CKD}(p<0.001)$. However, univariate and multivariate logistic regression showed that BMI was not a risk factor either for decreased GFR or for albuminuria. One study demonstrated that, as BMI 
medRxiv preprint doi: https://doi.org/10.1101/2020.10.19.20215004; this version posted October 21, 2020. The copyright holder for this preprint (which was not certified by peer review) is the author/funder, who has granted medRxiv a license to display the preprint in perpetuity.

All rights reserved. No reuse allowed without permission.

decreased, the incidence of ESRD also declined. However, this does not suggest that low BMI impliesa low risk of ESRD. ${ }^{25}$ In fact, Ramirez et al. demonstrated that patients with very low BMIs had an increased risk of proteinuria. ${ }^{11}$

Bosmaet al.suggested that the effects of BMI on renal function are not only limited to manifestations of obesity but also other factors, such as diabetes. ${ }^{26}$

The controversial impact of BMI on survival in general and renal failure in particular has been comprehensively reviewed by elsewhere. ${ }^{27,28}$ Briefly, in renal failure, body mass and particularly, BMI may be confused by hydration disorders, different stages of CKD and in the elderly. Therefore, to resolve the controversy around BMI in survival and renal failure, it is pivotal to take into account muscle mass, fat or adipose tissue mass, fat distribution and lean body mass rather than BMI. The molecular studies showed that, although, leptin and adiponectin secretion from adipose tissue require for energy and glucose homeostasis, the production of adipokines (TNF- $\alpha$, and IL-6) promote inflammation which might be complicated in diseases manifestation. Therefor instead of BMI and obesity, the direct mechanisms of adipose tissue on renal failure and survival must take into account.

Multiple studies in Iran demonstrated that female gender was the strongest risk factor for CKD. ${ }^{13,29}$ However, in this study, as table 1 shows, there were associations between GFR and gender, serum creatinine and gender $(p<0.001)$.Around $17.6 \%$ of males and $7.1 \%$ of females had moderately reduced GFR, and $0.7 \%$ of males and $0.5 \%$ of femaleshad severely reduced GFR. Therefore, the indices for renal function in females are generally better than in males.

In the present study, $10.8 \%, 68.3 \%, 20.2 \%, 0.5 \%$ and $0.2 \%$ of males were in CKD stages $1-5$, respectively. However, in females, there was a radically different distribution of CKD stages: $44.4 \%, 51.1 \%, 4.2 \%, 0.1 \%$ and $0.2 \%$ for stages $1-5$, respectively $(p<0.001)$. Although GFR has a symmetric normal distribution (Fig.1), the $\mathrm{Al} / \mathrm{Cr}$ ratio does not.Most of the subjects (40\%) had $\mathrm{Al} / \mathrm{Cr}$ ratios between $\sim 5$ and 24.99 , and $72.6 \%$ of subjects were fallen 
medRxiv preprint doi: https://doi.org/10.1101/2020.10.19.20215004; this version posted October 21, 2020. The copyright holder for this preprint (which was not certified by peer review) is the author/funder, who has granted medRxiv a license to display the preprint in perpetuity.

All rights reserved. No reuse allowed without permission.

between 60 and $100 \mathrm{~mL} / \mathrm{min} / 1.73 \mathrm{~m} 2$ for the GFR index.However, as previously suggested,differential errors in GFR estimation cannot be denied. ${ }^{9}$

The prevalence of CKD increases with age, as expected (Fig. 2).For example, the subjects in stage 3 increased from $1.30 \%$ in the age group $<30$ to $3 \%, 10 \%, 23.3 \%$ and $39.8 \%$ in age groups 30-39, 60-69 and >70 years, respectively. There were not any case of stages of 4 and 5 in age groups $<30,30-39,40-59$ and $60-69$. However,there was a $0.30 \%$ occurrence of stage 4 and a $0.40 \%$ occurrence of stage 5 in the age group $40-59$ and was a $1 \%$ occurrence for the age groups $>70$ years. These trends in increasing CKD stages in accordance with age were expected, as GFRs below $90 \mathrm{~mL} / \mathrm{min} / 1.73 \mathrm{~m}^{2}$ decreases with age.

Finally, there are limitations in this study; we did not consider deeply the socioeconomic condition of household. Using MDRD method, we did not measure serum creatinine and urine albumin in an interval time in negative subjects to reach lowest bias as finding curable acute kidney can effect on our CKD staging. The dietary history and herbal medications which may impact on kidney function did not record.

In conclusion, these findings show that interpretation of the high prevalence of CKD in this population should be considered in the context of the changes in human behaviours, addiction, and diseasetherapy vs. prevention, etiology, disease severity and co-occurring diseases.

Albuminuria is the strongest risk factor for CKD progression and increased risk of cardiovascular diseases. ${ }^{30}$ Reduced GFR in chronic kidney disease, particularly in stages 3 and 4, is associated with complications in the cardiovascular system and high costs of treatment in end-stage renal disease. Taken together, more initiatives are needed to reduce the incidence of CKD, such as greater responsibility among health authorities, an emphasis on therapy instead of prevention, and collecting more reliable data to predict complications of reduced GFR, kidney disease progression and cardiovascular manifestations. Therefore, it 
medRxiv preprint doi: https://doi.org/10.1101/2020.10.19.20215004; this version posted October 21, 2020. The copyright holder for this preprint (which was not certified by peer review) is the author/funder, who has granted medRxiv a license to display the preprint in perpetuity.

All rights reserved. No reuse allowed without permission.

isnecessary to establish a world scientific program for reducing CKD as an important cause of disease complications and costs for governments. For example, it is pivotal to establish diagnostic guidelines for early stages of CKD that very likely to prevent progression toward (ESRD) and cardiovascular diseases.

In our country, attention to CKD and its preventive programs is very low, particularly in the early stages of $\mathrm{CKD}$, but the cost of treatment, particularly for ESRD, is very high. Therefore, lack of planning for CKD prevention and reliance on treatment is expected to progress ESDR even more dramatically as the population continues to age.

\section{Abbreviations} triglyceride; WBC,White blood cells.

\section{ACKNOWLEDGEMENTS}

The authors have great thank to Mrs ShohrehYaghootkar who sorted all questionnaires, clinical history, laboratory tests and entered the data to the SPSS software. We greatly appreciate to Mrs SamanehAmiri was our great colleague in arrangement of sample collections from 20 Health centres and running laboratory tests in the ACECR-Central Medical Lab.This study was financially supported by the Vice-Chancellor for Research and Technology, Mashhad University of Medical Sciences, Mashhad, Iran, under Grant [MUMS 87099].

\section{CONFLICT OF INTEREST}


medRxiv preprint doi: https://doi.org/10.1101/2020.10.19.20215004; this version posted October 21, 2020. The copyright holder for this preprint (which was not certified by peer review) is the author/funder, who has granted medRxiv a license to display the preprint in perpetuity.

All rights reserved. No reuse allowed without permission.

The authors declare that they have no conflict of interest.

\section{ETHICS APPROVAL AND INFORM CONSENT}

All procedures performed in studies involving human participants were in accordance with the ethical standards of the institutional and/or national research committee and with the 1964 Helsinki declaration and its later amendments or comparable ethical standards. This study was reviewed, approved and supervised by the Biomedical Research Ethics Committee of Mashhad University of Medical Sciences [IR.MUMS.REC.87099]. Informed consent was obtained from all individual participants included in the study.

\section{DATA AND MATERIALS AVAILABILITY STATEMENT}

The data that support the findings of this study are included in this manuscript and available from the corresponding author (S.A.R. Rezaee)upon reasonable request.

\section{AUTHOR'S CONTRIBUTIONS}

S.A.R. Rezaee and T. Hassannia designed the study and arranged the laboratory tests. M. Khajedaluee did the statistical designs and supervised the data collections. S.A.R. Rezaee and

S. Ahmadi Ghezeldasht supervised laboratory tests supervision and quality controls. T. Hassannia and M. Khajahdaluee run the workshops for physicians and questioners. $\mathrm{M}$. Khajedaluee and S. Ahmadi Ghezeldasht performed the statistical analysis of the data. R. Hekmat as nephrologist was one of research advisors, S. Ahmadi Ghezeldasht and A. the manuscript. 
medRxiv preprint doi: https://doi.org/10.1101/2020.10.19.20215004; this version posted October 21, 2020. The copyright holder for this preprint (which was not certified by peer review) is the author/funder, who has granted medRxiv a license to display the preprint in perpetuity.

All rights reserved. No reuse allowed without permission.

\section{REFERENCES}

357

1. Haroun MK, Jaar BG, Hoffman SC, Comstock GW, Klag MJ, Coresh J. Risk factors for chronic kidney disease: a prospective study of 23,534 men and women in Washington County, Maryland. J Am Soc Nephrol 2003;14(11):2934-41.

2. Stenvinkel P. Chronic kidney disease: a public health priority and harbinger of premature cardiovascular disease. J Intern Med 2010;268(5):456-67.

3. Gansevoort RT, Correa-Rotter R, Hemmelgarn BR, Jafar TH, Heerspink HJ, Mann JF, et al. Chronic kidney disease and cardiovascular risk: epidemiology, mechanisms, and prevention. Lancet 2013;382(9889):339-52.

4. Levey A, Atkins R, Coresh J, Cohen E, Collins A, Eckardt K-U, et al. Chronic kidney disease as a global public health problem: approaches and initiatives-a position statement from Kidney Disease Improving Global Outcomes. Kidney international 2007;72(3):247-59.

5. Locatelli F, Vecchio LD, Pozzoni P. The importance of early detection of chronic kidney disease. Nephrol Dial Transplant 2002;17 Suppl 11:2-7.

6. Ruggenenti P, Schieppati A, Remuzzi G. Progression, remission, regression of chronic renal diseases. Lancet 2001;357(9268):1601-8.

7. Levey AS, Coresh J, Balk E, Kausz AT, Levin A, Steffes MW, et al. National Kidney Foundation practice guidelines for chronic kidney disease: evaluation, classification, and stratification. Ann Intern Med 2003;139(2):137-47.

8. Verhave JC, Balje-Volkers CP, Hillege HL, de Zeeuw D, de Jong PE. The reliability of different formulae to predict creatinine clearance. J Intern Med 2003;253(5):56373.

9. Coresh J, Selvin E, Stevens LA, Manzi J, Kusek JW, Eggers P, et al. Prevalence of chronic kidney disease in the United States. JAMA 2007;298(17):2038-47. 
medRxiv preprint doi: https://doi.org/10.1101/2020.10.19.20215004; this version posted October 21, 2020. The copyright holder for this preprint (which was not certified by peer review) is the author/funder, who has granted medRxiv a license to display the preprint in perpetuity.

All rights reserved. No reuse allowed without permission.

10. Imai E, Horio M, Iseki K, Yamagata K, Watanabe T, Hara S, et al. Prevalence of chronic kidney disease (CKD) in the Japanese general population predicted by the MDRD equation modified by a Japanese coefficient. Clin Exp Nephrol 2007;11(2):156-63.

11. Ramirez SP, McClellan W, Port FK, Hsu SI. Risk factors for proteinuria in a large, multiracial, southeast Asian population. J Am Soc Nephrol 2002;13(7):1907-17.

12. Chadban SJ, Briganti EM, Kerr PG, Dunstan DW, Welborn TA, Zimmet PZ, et al. Prevalence of kidney damage in Australian adults: The AusDiab kidney study. $J$ Am Soc Nephrol 2003;14(7 Suppl 2):S131-8.

13. Hosseinpanah F, Kasraei F, Nassiri AA, Azizi F. High prevalence of chronic kidney disease in Iran: a large population-based study. BMC Public Health 2009;9(1):44.

14. Levey A, Greene T, Kusek J, Beck G. A simplified equation to predict glomerular filtration rate from serum creatinine [Abstract]: J Am Soc. Nephrol 2000;11.

15. Sepanlou SG, Barahimi H, Najafi I, Kamangar F, Poustchi H, Shakeri R, et al. Prevalence and determinants of chronic kidney disease in northeast of Iran: Results of the Golestan cohort study. PLoS One 2017;12(5):e0176540.

16. Muntner P, He J, Vupputuri S, Coresh J, Batuman V. Blood lead and chronic kidney disease in the general United States population: results from NHANES III. Kidney Int 2003;63(3):1044-50.

17. Martín-Cleary C, Ortiz A. CKD hotspots around the world: where, why and what the lessons are. A CKJ review series. Clinical kidney journal 2014;7(6):519-23.

18. Zhang L, Zhang P, Wang F, Zuo L, Zhou Y, Shi Y, et al. Prevalence and factors associated with CKD: a population study from Beijing. Am J Kidney Dis 2008;51(3):373-84. 
medRxiv preprint doi: https://doi.org/10.1101/2020.10.19.20215004; this version posted October 21, 2020. The copyright holder for this preprint (which was not certified by peer review) is the author/funder, who has granted medRxiv a license to display the preprint in perpetuity.

All rights reserved. No reuse allowed without permission.

405

406

407

408

409

410

411

412

413

414

415

416

417

418

419

420

421

422

423

424

425

426

427

428

19. Conway B, Webster A, Ramsay G, Morgan N, Neary J, Whitworth C, et al. Predicting mortality and uptake of renal replacement therapy in patients with stage 4 chronic kidney disease. Nephrol Dial Transplant 2009;24(6):1930-7.

20. Poggio ED, Rule AD. A critical evaluation of chronic kidney disease-should isolated reduced estimated glomerular filtration rate be considered a 'disease'? : Oxford University Press; 2008.

21. Van Pottelbergh G, Bartholomeeusen S, Buntinx F, Degryse J. The evolution of renal function and the incidence of end-stage renal disease in patients aged $\geq 50$ years. Nephrology Dialysis Transplantation 2011;27(6):2297-303.

22. Winearls CG, Glassock RJ. Classification of chronic kidney disease in the elderly: pitfalls and errors. Nephron Clin Pract 2011;119 Suppl 1(Suppl. 1):c2-4.

23. De Nicola L, Zoccali C. Chronic kidney disease prevalence in the general population: heterogeneity and concerns. Nephrol Dial Transplant 2016;31(3):331-5.

24. Stanifer JW, Maro V, Egger J, Karia F, Thielman N, Turner EL, et al. The epidemiology of chronic kidney disease in Northern Tanzania: a population-based survey. PLoS One 2015;10(4):e0124506.

25. Iseki K, Ikemiya Y, Kinjo K, Inoue T, Iseki C, Takishita S. Body mass index and the risk of development of end-stage renal disease in a screened cohort. Kidney Int 2004;65(5):1870-6.

26. Bosma RJ, Homan JJ, Heide V, Oosterop EJ, de Jong PE, Navis G. Body mass index is associated with altered renal hemodynamics in non-obese healthy subjects. Kidney international 2004;65(1):259-65.

27. Cuppari L. Diagnosis of obesity in chronic kidney disease: BMI or body fat? Nephrol Dial Transplant 2013;28 Suppl 4:iv119-21. 
medRxiv preprint doi: https://doi.org/10.1101/2020.10.19.20215004; this version posted October 21, 2020. The copyright holder for this preprint

(which was not certified by peer review) is the author/funder, who has granted medRxiv a license to display the preprint in perpetuity.

All rights reserved. No reuse allowed without permission.

429

430

431

432

433

434

435

436

437

438
28. Mafra D, Guebre-Egziabher F, Fouque D. Body mass index, muscle and fat in chronic kidney disease: questions about survival. Nephrol Dial Transplant 2008;23(8):2461-

6.

29. Malekmakan L, Khajehdehi P, Pakfetrat M, Malekmakan A, Mahdaviazad H, Roozbeh J. Prevalence of chronic kidney disease and its related risk factors in elderly of southern iran: a population-based study. ISRN Nephrol 2013;2013:427230.

30. Keith DS, Nichols GA, Gullion CM, Brown JB, Smith DH. Longitudinal follow-up and outcomes among a population with chronic kidney disease in a large managed care organization. Archives of internal medicine 2004;164(6):659-63. 
medRxiv preprint doi: https://doi.org/10.1101/2020.10.19.20215004; this version posted October 21, 2020. The copyright holder for this preprint

(which was not certified by peer review) is the author/funder, who has granted medRxiv a license to display the preprint in perpetuity.

All rights reserved. No reuse allowed without permission.

\section{FIGURE LEGENDS}

441

FIGURE 1. The distribution of estimated A, GFR and $\mathbf{B}$, albuminuria.

442

FIGURE 2. Prevalence of Chronic Kidney Disease (CKD) Stages by Age Group. The under curve area demonstrates the percentage of CKD stages for each age categories. 
medRxiv preprint doi: https://doi.org/10.1101/2020.10.19.20215004; this version posted October 21, 2020. The copyright holder for this preprint (which was not certified by peer review) is the author/funder, who has granted medRxiv a license to display the preprint in perpetuity. All rights reserved. No reuse allowed without permission.

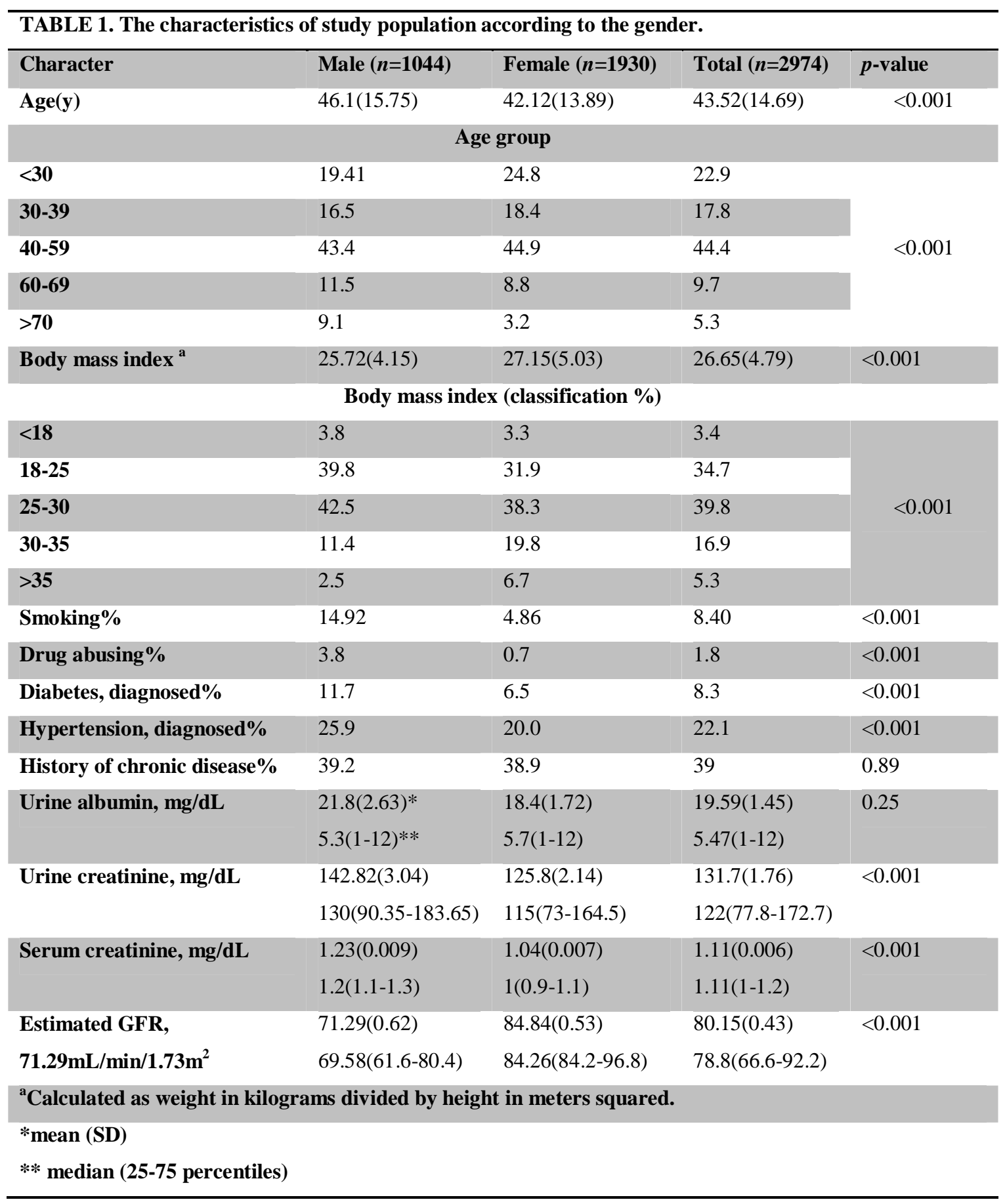


medRxiv preprint doi: https://doi.org/10.1101/2020.10.19.20215004; this version posted October 21, 2020. The copyright holder for this preprint (which was not certified by peer review) is the author/funder, who has granted medRxiv a license to display the preprint in perpetuity.

All rights reserved. No reuse allowed without permission.

TABLE 2. Prevalence of A, Kidney Function and B, Albuminuria categories in the study population.

\begin{tabular}{|c|c|c|c|c|}
\hline $\begin{array}{l}\text { Kidney function (GFR), } \\
\mathrm{mL} / \mathrm{min} / 1.73 \mathrm{~m} 2\end{array}$ & $\begin{array}{l}\text { Male } \\
(n=1044)\end{array}$ & Female $(n=1930)$ & Total $(n=2974)$ & $p$-value \\
\hline Normal ( $\geq 90)$ & 12.1 & 40.3 & 30.6 & \multirow{4}{*}{$<0.001$} \\
\hline Mildly reduced (60-89) & 69.5 & 52 & 58 & \\
\hline Moderately reduced (30-59) & 17.6 & 7.1 & 10.7 & \\
\hline Severely reduced $(<30)$ & 0.7 & 0.5 & 0.6 & \\
\hline
\end{tabular}

Albuminuria (ACR), mg/gb

\begin{tabular}{|c|c|c|c|c|}
\hline $\begin{array}{l}\text { Overall } \\
\text { Normal }\end{array}$ & 12.6 & 11.4 & 11.8 & 0.49 \\
\hline $\begin{array}{l}\text { GFR } \geq 90 \\
\mathrm{~mL} / \mathrm{min} / 1.73 \mathrm{~m} 2\end{array}$ & 8.8 & 11.9 & 11.6 & 0.48 \\
\hline $\begin{array}{l}\text { GFR 60-89 } \\
\mathrm{mL} / \mathrm{min} / 1.73 \mathrm{~m} 2\end{array}$ & 12.6 & 10.3 & 11.3 & 0.29 \\
\hline $\begin{array}{l}\text { GFR 30-59 } \\
\mathrm{mL} / \mathrm{min} / 1.73 \mathrm{~m} 2\end{array}$ & 14.8 & 16.1 & 15.1 & 0.85 \\
\hline $\begin{array}{l}\text { GFR }<30 \\
\mathrm{~mL} / \mathrm{min} / 1.73 \mathrm{~m} 2\end{array}$ & 0.0 & 0.0 & 0.0 & \\
\hline
\end{tabular}


medRxiv preprint doi: https://doi.org/10.1101/2020.10.19.20215004; this version posted October 21, 2020. The copyright holder for this preprint (which was not certified by peer review) is the author/funder, who has granted medRxiv a license to display the preprint in perpetuity.

All rights reserved. No reuse allowed without permission.

TABLE 3.Prevalence of Chronic Kidney Disease (CKD) according to the stages.

\begin{tabular}{ccccc}
\hline CKDStage & Male $(\boldsymbol{n}=\mathbf{1 0 4 4})$ & Female $(\boldsymbol{n}=\mathbf{1 9 3 0})$ & Total $(\boldsymbol{n}=\mathbf{2 9 7 4})$ & $\boldsymbol{p}$-value \\
$\mathbf{1}$ & 10.8 & 44.4 & 32.9 & \\
$\mathbf{2}$ & 68.3 & 51.1 & 57 & \\
$\mathbf{3}$ & 20.2 & 4.2 & 9.7 & $<0.001$ \\
$\mathbf{4}$ & 0.5 & 0.1 & 0.2 & \\
$\mathbf{5}$ & 0.2 & 0.2 & 0.2 & \\
Total & 100 & 100 & 100 & \\
\hline
\end{tabular}

452

453

454 
medRxiv preprint doi: https://doi.org/10.1101/2020.10.19.20215004; this version posted October 21, 2020. The copyright holder for this preprint (which was not certified by peer review) is the author/funder, who has granted medRxiv a license to display the preprint in perpetuity.

All rights reserved. No reuse allowed without permission.

TABLE 4. A) Logistic Regression of Decreased Estimated Glomerular Filtration Rate (GFR)<60 $\mathrm{mL} / \mathrm{min} / 1.73 \mathrm{~m} 2$ in

\begin{tabular}{|l|l|l|l|l|l|l|l|}
\hline & $\mathrm{B}$ & $\mathrm{SE}$ & $\mathrm{P}$ & \multicolumn{3}{|l|}{ Univariate } & \multicolumn{2}{l|}{ Multivariate } \\
\cline { 5 - 8 } & & & & OR & $95 \% \mathrm{Cl}$ & OR & $95 \% \mathrm{Cl}$ \\
\hline $\begin{array}{l}\text { Adjusted for } \\
\text { age }\end{array}$ & 0.069 & 0.005 & $<0.001$ & 1.07 & $1.06-1.08$ & 1.06 & $1.05-1.07$ \\
\hline Gender (male) & 1.015 & 0.135 & $<0.001$ & 2.76 & $2.12-3.59$ & 2.14 & $1.59-2.89$ \\
\hline $\begin{array}{l}\text { Diagnosed } \\
\text { diabetes }\end{array}$ & 0.674 & 0.201 & 0.001 & 1.96 & $1.32-2.91$ & 1.07 & $0.69-1.66$ \\
\hline $\begin{array}{l}\text { Diagnosed } \\
\text { hypertension }\end{array}$ & 0.982 & 0.142 & $<0.001$ & 2.67 & $2.02-3.52$ & 1.39 & $1.04-1.92$ \\
\hline $\begin{array}{l}\text { Body mass } \\
\text { index }\end{array}$ & 0.015 & 0.014 & 0.29 & 1.01 & $0.97-1.04$ & 0.99 & $0.96-1.02$ \\
\hline B) & & & & & & \\
\hline
\end{tabular}

B) Logistic Regression of Albuminuria

\begin{tabular}{|c|c|c|c|c|c|c|c|}
\hline & \multirow[t]{2}{*}{ B } & \multirow[t]{2}{*}{ SE } & \multirow[t]{2}{*}{$\mathrm{P}$} & \multicolumn{2}{|c|}{ Univariate } & \multicolumn{2}{|c|}{ multivariate } \\
\hline & & & & OR & $95 \% \mathrm{Cl}$ & OR & $95 \% \mathrm{Cl}$ \\
\hline $\begin{array}{l}\text { Adjusted for } \\
\text { age }\end{array}$ & 0.021 & 0.006 & $<0.001$ & 1.02 & $1.01-1.03$ & 1.02 & $1.002-1.03$ \\
\hline Gender (male) & 0.112 & 0.167 & 0.5 & 1.11 & $0.81-1.55$ & 0.86 & $0.59-1.25$ \\
\hline $\begin{array}{l}\text { Diagnosed } \\
\text { diabetes }\end{array}$ & 1.053 & 0.226 & $<0.001$ & 2.86 & $1.84-4.46$ & 2.61 & $1.62-4.22$ \\
\hline $\begin{array}{l}\text { Diagnosed } \\
\text { hypertension }\end{array}$ & 0.563 & 0.183 & 0.002 & 1.75 & $1.22-2.51$ & 1.16 & $0.76-1.78$ \\
\hline $\begin{array}{l}\text { Body mass } \\
\text { index }\end{array}$ & 0.015 & 0.017 & 0.37 & 1.01 & $0.98-1.05$ & 0.99 & $0.96-1.03$ \\
\hline
\end{tabular}




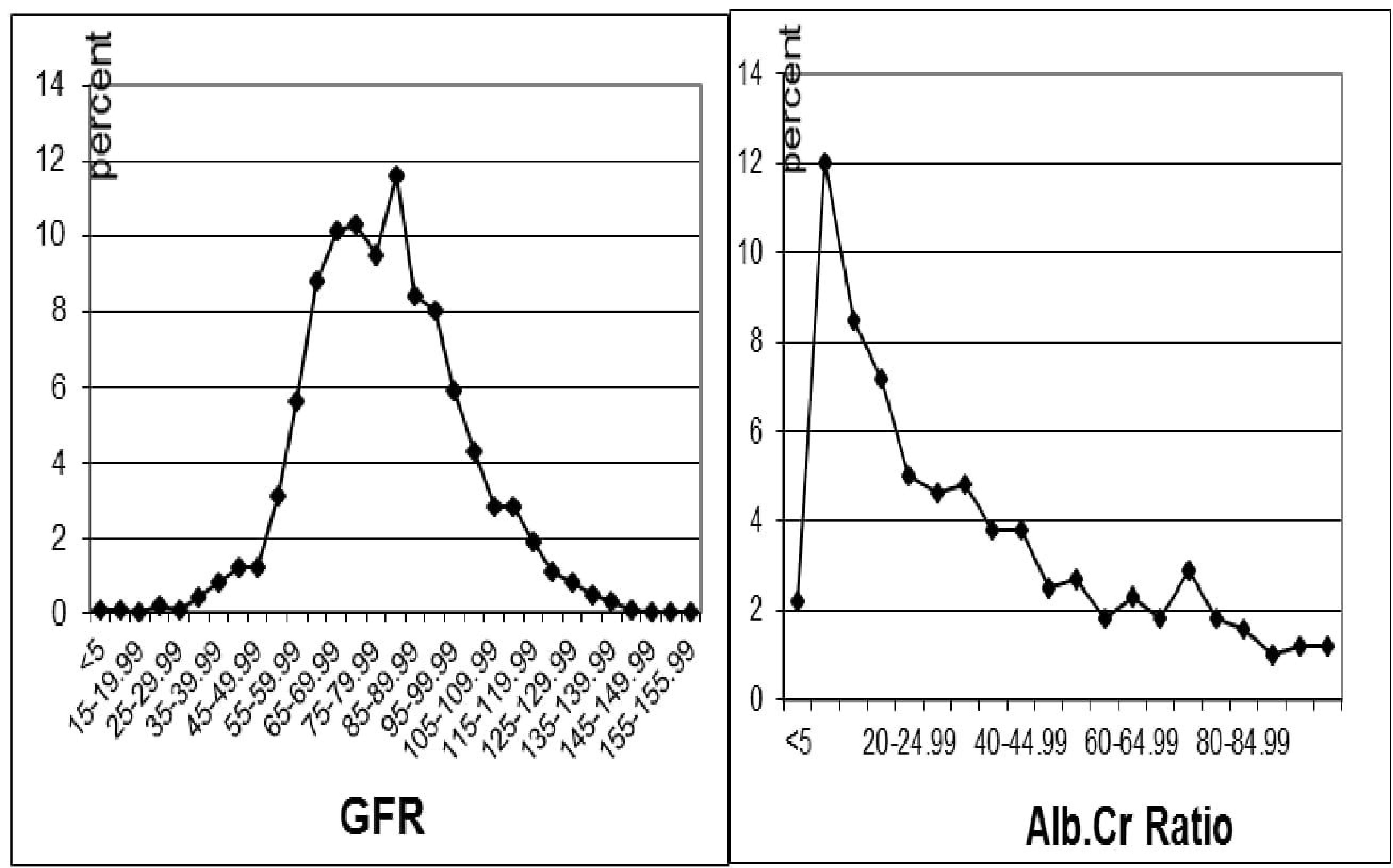




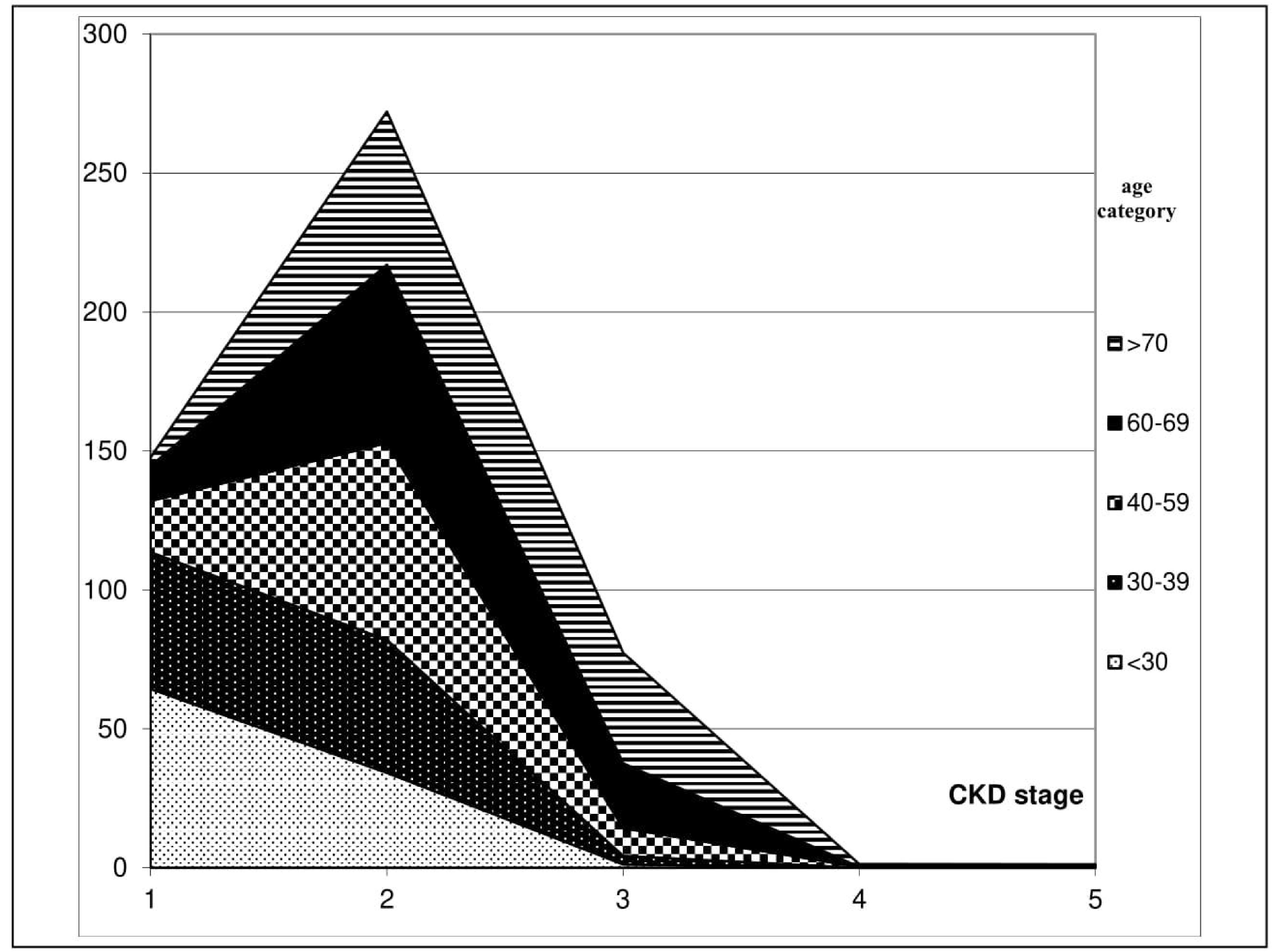

